\title{
Growth allocation in Laminaria hyperborea (Laminariales, Phaeophyceae) in relation to age and wave exposure
}

\author{
Kjersti Sjøtun*, Stein Fredriksen \\ Department of Biology, University of Oslo, PO Box 1069 Blindern, N-0316 Oslo, Norway
}

\begin{abstract}
Morphological development of Laminaria hyperborea was examined at localities with different degrees of wave exposure. Biomass data were converted to estimates of annual growth of lamina, stipe and hapteron. Allocation of annual growth to the hapteron constituted a small amount of the total production, but increased with increasing wave exposure. At the most sheltered locality, lamina growth amounted to between 80 and $95 \%$ of total growth in all age groups, and lamina to stipe ratios (fresh weight) were about 10 . A higher portion of the annual growth was allocated to the stipe at the more wave-exposed localities. This resulted in lamina to stipe ratios of between 1 and 2 in old plants, but within these localities no gradual decrease in lamina to stipe ratio with increasing wave exposure was observed. At some localities a maximum of growth allocation to the stipe was found in the intermediate age groups. This was most pronounced at the locality with the highest density of canopy plants and intermediate wave exposure. Also, at this locality the stipes were longer in relation to their weight than at the other localities. These results indicate that light environment, in addition to wave exposure, may influence the stipe morphology and the relationship between stipe and lamina growth. At one station stipe growth was also calculated in individual tagged plants using the lengthweight relationship. The results agreed with those obtained by the biomass method. The highest allocation of growth to the stipes was found in 3 and 4 yr old plants. Maximum annual stipe growth (weight increase) occurred in 4 and 5 yr old plants and decreased in older plants, while maximum lamina growth was found in the oldest plants.
\end{abstract}

KEY WORDS: Laminaria hyperborea Kelp Growth allocation Age Morphology Plasticity Wave exposure

\section{INTRODUCTION}

Morphological plasticity is common in macroalgae. Many kelp species have wide, thin lamina when growing in sheltered areas, and narrow, thick lamina at wave-exposed sites (Sundene 1964, Norton et al. 1981). The ability to adapt the shape of the thallus to the environment may be of functional and ecological significance for the algae.

Laminaria hyperborea (Gunn.) Fosl. is an example of a kelp in which morphology changes according to

\footnotetext{
- Present address: Department of Fisheries and Marine Biology, University of Bergen, Bergen High Technology Centre, N-5020 Bergen, Norway. E-mail: kjersti.sjoetun@ifm.uib.no
}

wave exposure. At wave-exposed localities the most typical form of $L$. hyperborea develops; it has a digitated lamina and a long stipe. The fresh weight ratio between lamina and stipe is about $1: 1$ in canopy plants (Kain 1971a). The meristem activity in the lamina during the seasonal growth period is complicated (Kain 1976a), and at wave-exposed sites it results in a fanshaped lamina which is split into many fingers (Kain 1971b). In sheltered areas, the ratio between lamina and stipe fresh weight is much higher than at waveexposed sites, about 10:1 (Kain 1971a), and the lamina is entire or split into a few segments. The relationship between the 2 morphological forms of $L$. hyperborea was investigated by Svendsen \& Kain (1971).

Laminaria hyperborea can reach an age of more than $10 \mathrm{yr}$. The age varies among other things with latitude 
(Kain 1971b, Sjøtun et al. 1993). Annual stipe and hapteron growth is retained on the plant, whereas the lamina is shed during spring when the new lamina appears. The stipe increases in length and thickness, and new hapteron branches are formed throughout the life span of the plant. Some aspects of the morphology change as the plants grow in size and age, and may be described in allometric terms. For instance, lengthto-weight ratio of stipes and the ratio between the weights of lamina and stipe change as plants age Morphological changes may be related to both ontogenetic development and morphological adaptations to environmental conditions.

Laminaria hyperborea occurs in highest abundance in wave-exposed areas, where monospecific stands with densities of up to $40 \mathrm{~kg}$ fresh $w \mathrm{t} \mathrm{m}^{-2}$ can be found (Sivertsen 1991). The canopy-forming plants can reduce the light penetration to the bottom by as much as $90 \%$ (Norton et al. 1977), and the growth of understorey plants of $L$. hyperborea is therefore probably severely light-limited in dense stands. Growth of young kelp plants in a dense kelp forest constitutes an analogous example to seedlings in a forest on land. Among land plants light-limitation can result in growth responses, e.g. etiolation, but as for algae the possible existence of such responses has seldom been investigated.

We have examined several populations of Laminaria hyperborea in order to establish how growth in various parts of the thallus modifies the morphology of the plants as they grow older Estimates of growth in different parts of L. hyperborea have been obtained from biomass data. In addition, growth of individual stipes during one period of rapid growth was examined in tagged plants at one locality. The localities examined are situated at $60^{\circ}$ and $65^{\circ} \mathrm{N}$, within the range of latitudes which seem to provide optimum conditions for the development of $L$. hyperborea kelp forests (Kain 1971b). In order to study how the morphological development is modified by the environment, the localities were chosen to represent a wide range of wave exposure. Also, the density of the populations studied was examined, in order to investigate whether growth in the different thallus parts of young plants was influenced by the density of the large, canopyforming plants. Possible adaptive significances of the observed phenotypic variation in L. hyperborea are discussed.

\section{MATERIALS AND METHODS}

Two localities in northern Norway (Stns 1 \& 2) and 3 in western Norway (Stns 3 to 5) were examined (Fig. 1). In both areas the localities are situated in an outer coastal archipelago and are no more than $15 \mathrm{~km}$ apart. The samples from Stns $1 \& 2$ were collected during 1991, and the samples from Stns 3 to 5 during 1992-1993.

Growth estimates using the biomass method. Samples of Laminaria hyperborea were collected in May and June at Stns 1 \& 3 to 5 and in September at Stn 2. At all stations the samples were collected at a depth of $5 \mathrm{~m}$ (below chart datum) by scuba-diving. At Stn 1 an area of $14 \mathrm{~m}^{2}$ was sampled; at Stns 2 to 5, plants were collected from an area of 2 to $3 \mathrm{~m}^{2}$ The exact location of each sample was chosen by a diver who swam over the kelp forest and dropped a frame haphazardly, except at Stn 1 where an area of 14 adjoining $1 \mathrm{~m}^{2}$ quadrats was sampled. At the other stations, between 4 and 6 samples (each of 0.5 or $1 \mathrm{~m}^{2}$ ) were taken within a distance of 10 to $20 \mathrm{~m}$, and are therefore considered to be representative for the local kelp population at each station. The samples from Stn 4 contained few small plants, and a number of small plants were therefore collected in addition. These were not included in the analyses of size distribution.

The thallus of each plant was divided into lamina, stipe and hapteron and weighed after removal of epiphytes. Lamina and stipe lengths were measured for each plant. The age of the plants was determined according to Kain (1963), by counting growth rings. At Stn 1 the sample contained a very large number of $1 \mathrm{yr}$ old plants, and randomly chosen subsamples of these were measured and weighed.

Biomass data from each station were converted into estimates of biomass production as described by Bellamy et al. (1973).

Seasonal stipe growth calculated at one locality. Bellamy et al. (1973) estimated annual stipe and hapteron growth as the average weight differences between age groups. The method is valid only if average stipe and hapteron growth in each age group shows no year-to-year variation at a locality. This may not be the case, and at Stn 4 an additional estimate of seasonal biomass production of the stipes was therefore made using a method based on the relationship between the length and weight of stipes.

At the beginning of February 1993, 140 plants were tagged at $5 \mathrm{~m}$ depth at Stn 4 . Stipe lengths of these plants were measured, and varied from 9 to $130 \mathrm{~cm}$. In June 1993 a total of 91 plants were recollected and harvested. Each plant was divided into lamina, stipe and hapteron. Epiphytes were removed from the stipe; the hapteron, stipe and lamina were weighed and the length of the stipe was measured and the age of each plant was determined

Stipe weights were calculated using the equation describing the relationship between stipe length and fresh wt. A second-degree polynomial regression of $\log -\log$ transformed values of stipe length and weight provided the best fitted curve (with highest value of 


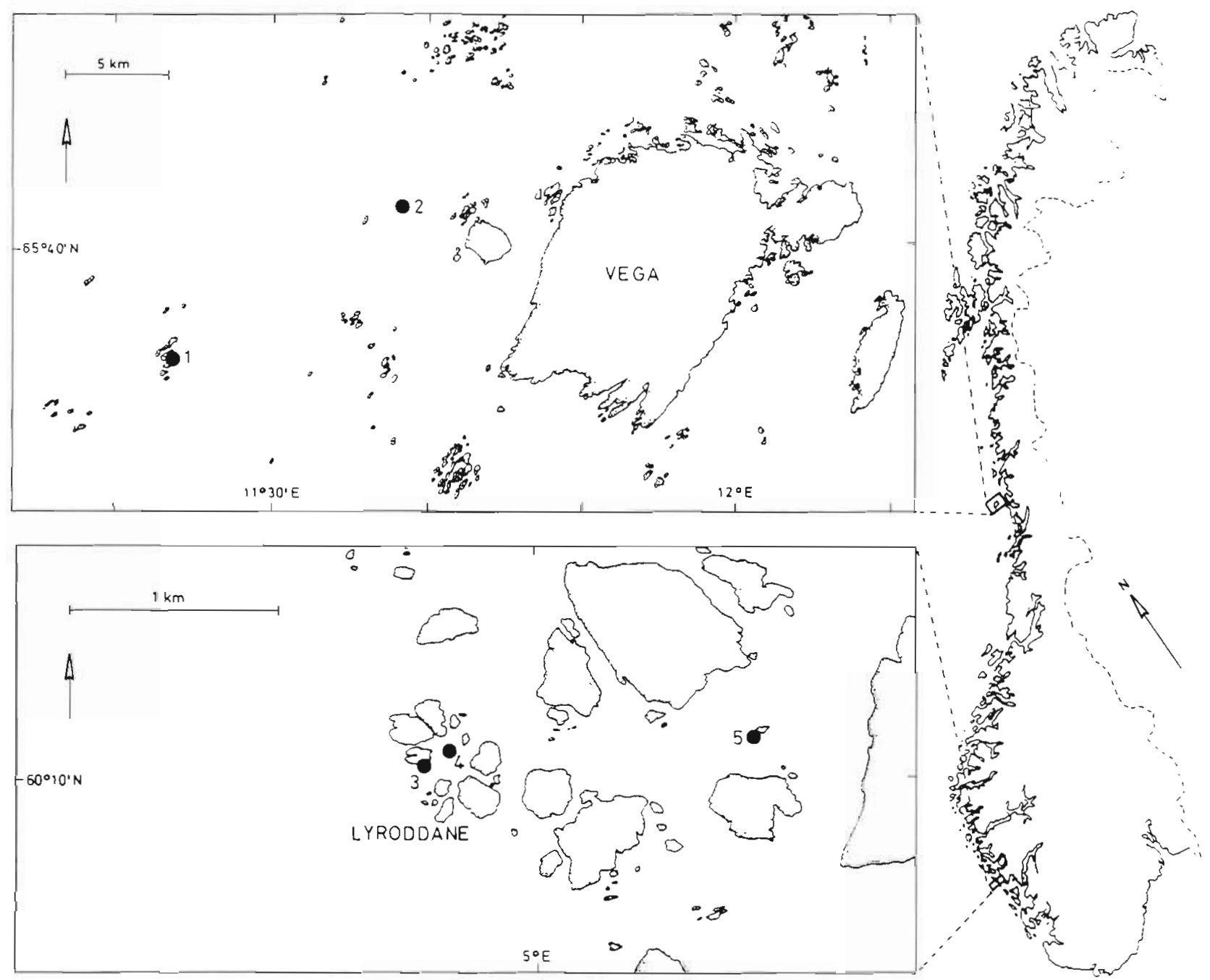

Fig. 1 Study sites in north Norway (Stns $1 \&$ 2) and in western Norway (Stns 3 to 5). Note the different scales of the 2 sections

$\mathrm{r}^{2}$ ) for the tagged plants harvested from $\operatorname{Stn} 4$ ( $\mathrm{n}=91$, $\left.p=0.0001, r^{2}=0.98\right)$. The stipe weight of each tagged plant was calculated from length measurements, and stipe production was estimated as the difference between calculated stipe weight in February and June.

Wave exposure. Wave exposure was estimated according to a modified sector method developed by Baardseth (1970). At each site the number of $10^{\circ} \mathrm{sec}-$ tors exposed to open sea was determined on a map. Each sector was assigned a relative wind force value (e) based on the mean force and frequency of wind during the last 5 yr (Oug et al. 1985), the wind data being given in 12 directions:

$$
e=\frac{n_{1} F_{1}}{100 S_{1}}+\frac{n_{2} F_{2}}{100 S_{2}}+\ldots+\frac{n_{n} F_{n}}{100 S_{n}}
$$

where $S_{n}$ is the number of open sectors in a given direction. $n_{n}$ is the number of observations of wind from a given direction, $F_{n}$ is the average strength of wind (Beaufort) from a given direction ( $\mathrm{n}=1$ to 12 ). Wind data from the weather station closest to each site were obtained from the Norwegian Meteorological Institute. The relative influence of the local topography, a fjord or the open sea, on the station, was reflected in the number of sectors containing open sea only at radii of $0.5,7$ and $100 \mathrm{~km}$ from the station (Oug et al. 1985). One value of (e) was calculated for each radius, $e_{1}, e_{2}$ and $e_{3}$ respectively. An estimated value of total wave exposure (E) was calculated from:

$$
E=\left[e_{1}+\left(10 e_{2}\right)+\left(100 e_{3}\right)\right] \times 10^{-1}
$$

where $e_{1}$ is the relative wind force value for sectors of radius $0.5 \mathrm{~km}, e_{2}$ is the relative wind force value for sectors of radius $7 \mathrm{~km}, e_{3}$ is the relative wind force value for sectors of radius $100 \mathrm{~km}$.

Statistical testing. Linear regressions were carried out on log-transformed stipe length and weight data at each station. In order to compare the length-adjusted 
weights of stipes, between stations and age groups, a 2-way analysis of covariance was carried out on log-transformed weights. The test was carried out on the age groups present at all stations (2 to 4 yr old plants), with log-transformed lengths as covariates. The age groups present among the tagged plants at Stn 4 were compared with respect to stipe growth and allocation of total net production to stipe growth using Tukey tests (Zar 1984). Percentage data were arcsine-transformed before the statistical tests were applied.

Data were tested for heteroscedasticity $\left(F_{\text {max }}{ }^{-}\right.$ test) before statistical testing. Results of statistical tests were considered significant when $p<0,05$ if no different significance level is given.

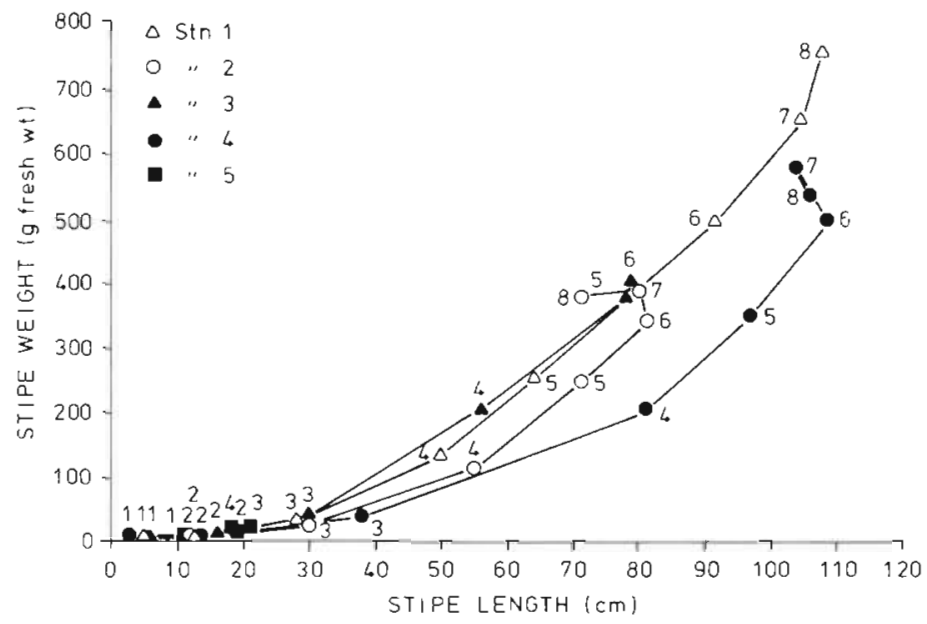

Fig. 2. Average stipe lengths and corresponding stipe weights in all age groups (age groups indicated by number); $n=3$ to 112

\section{RESULTS}

Wave exposure was highest at Stn 3 , while Stns 4 \& 1 were slightly more sheltered (Table 1). Stns $2 \& 5$ had no open sectors with radii $100 \mathrm{~km}$, and may be characterized as semiexposed and sheltered, respectively.

Stipe and lamina characteristics. A curvilinear relationship between stipe length and weight was found at all stations (Fig. 2). Linear regression lines could be fitted to log-transformed data from Stns 1 to 5 ( $r=0.93$ to 0.99 ) The oldest plants ( 7 to $8 \mathrm{yr}$ ) at Stris 1 \& 4 carried the largest stipes (average weight, 0.5 to $0.8 \mathrm{~kg}$; length, 100 to $110 \mathrm{~cm}$ ). At Stn 5 no plants older than 4 yr were found. Stipe size varied very little between the 2 to 3 oldest age groups at each station (Fig. 2).

The analysis of covariance on stipe weights gave significant differences of length-adjusted age groups between stations. The test for non parallelism between regression lines was not significant, but the interaction term was significant, showing that weight increases somewhat faster with age at some stations than others. From Fig. 2 it is evident that especially Stn 4 deviates from the other stations, in having longer stipes in relation to the weights.

Table 1. Number of $10^{\circ}$ sectors contaning open sea only at a distance of $0.5 \mathrm{~km}$ (R1), $7 \mathrm{~km}$ (R2) and $100 \mathrm{~km}$ (R3) from land at Stns 1 to 5. Stations are ranked according to estimated wave exposure $(E)$

\begin{tabular}{|rrrrr|}
\hline Stn & R1 & R2 & R3 & $E$ \\
\hline 3 & 7 & 6 & 6 & 888 \\
4 & 4 & 3 & 3 & 478 \\
1 & 16 & 10 & 1 & 249 \\
2 & 20 & 3 & 0 & 68 \\
5 & 7 & 0 & 0 & 7 \\
\hline
\end{tabular}

The laminae of plants older than 1 yr were digitated at all stations. At Stn 5 the ratio between lamina weight and stipe weight varied between 8.5 and 11.5 (Fig. 3). At the other stations the ratio decreased from 8.5 to

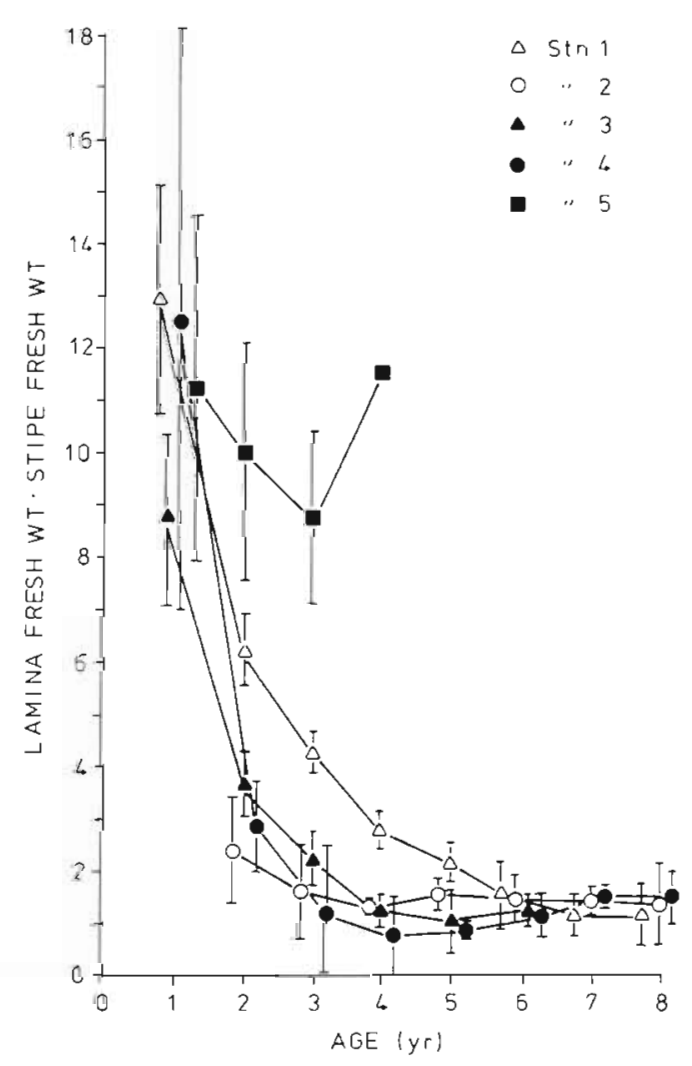

Fig. 3. Average ratios between lamına and stıpe fresh wt with $95 \%$ confidence limits. Confidence limits which include zero are not shown; $n=3$ to 112 
13 in 1 yr old plants to between 1 and 1.5 in plants older than $5 \mathrm{yr}$ (Fig. 3). At Stn 1 the ratio between lamina and stipe weight decreased less abruptly than at Stns 2 to 4 , and was higher in the 2 to 5 yr old plants at Stn 1 than at Stns 2 to 4 (Fig. 3).

There was a distinct canopy layer with high densities of plants with long stipes and low densities of intermediate-sized plants at Stns $2 \& 4$. Stn 4 had the highest density of plants in the canopy layer (Fig. 4). At Stns 1 \& 3 the plants showed a general decrease in number with increasing stipe length, and the density of plants with long stipes was lower at Stn 1 . At Stn 5 no plants with stipes longer than $40 \mathrm{~cm}$ were present.

Growth in different parts of the thallus: biomass method. The hapteron production constituted a low proportion of the total production (maximum 14\%) (Fig. 5). Also, at each station the proportion of hapteron growth showed no pronounced variation with age. A significant relationship (linear regression, $p=0.0001$, $r^{2}=0.45$ ) between the proportion of hapteron growth and estimated degree of wave exposure was found, with the highest allocation of growth to the haptera at the most wave-exposed stations (Fig. 6).

Lamina production constituted more than $50 \%$ of total production in most age classes at all stations (Fig. 5). At Stn 5 lamina production was very high compared to that of other parts of the thallus, and amounted to between 80 and $95 \%$ of total growth in all age groups. The samples from Stns $2 \& 4$ (1993) did not contain any 1 yr old plants, but at Stns $3 \& 4$ (1992), the allocation of annual production to the lamina was highest in the youngest and oldest age groups (Fig. 5).

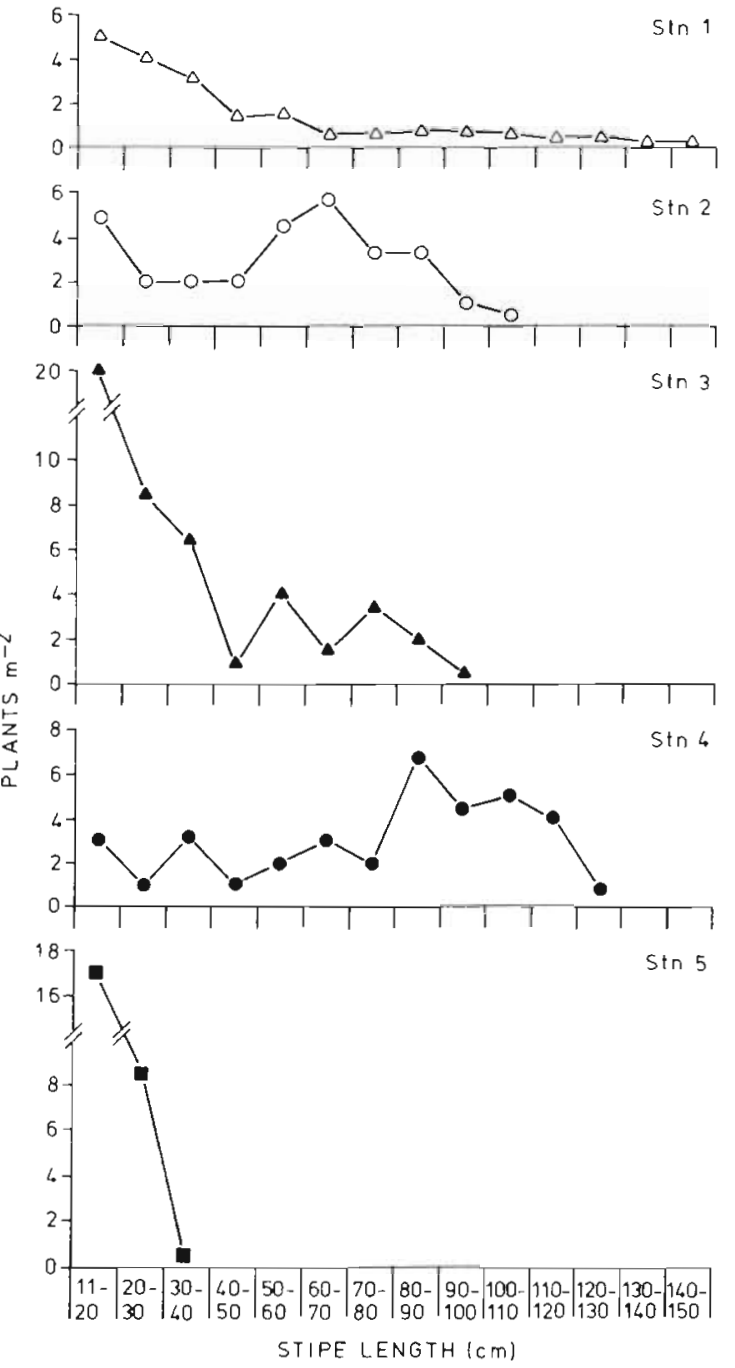

STIPE LENGTH (cm)

Fig. 4. Frequency of plants of different stipe length in intervals from 11 to $20 \mathrm{~cm}$ to between 140 and $150 \mathrm{~cm}$
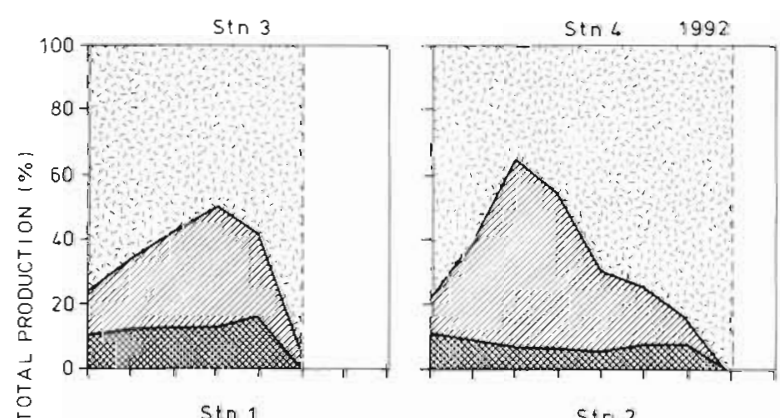

$\sin 2$
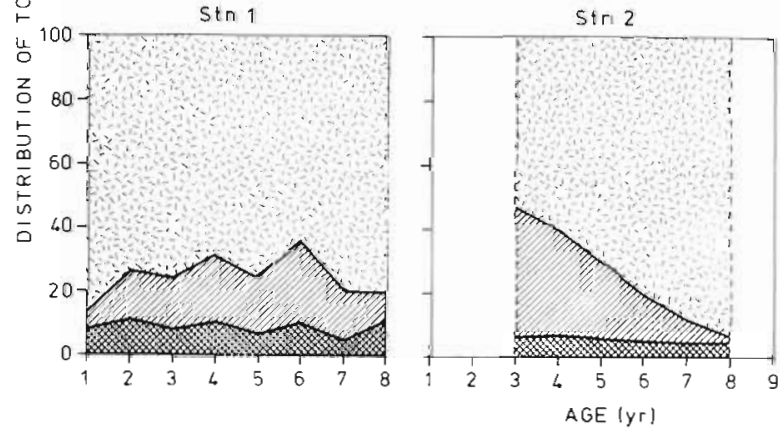

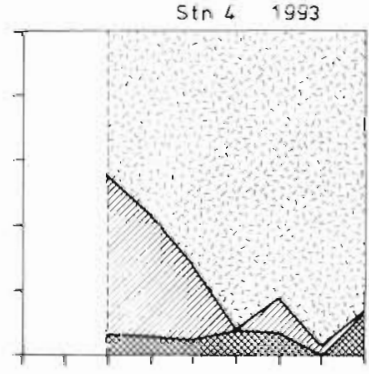

$\sin 5$

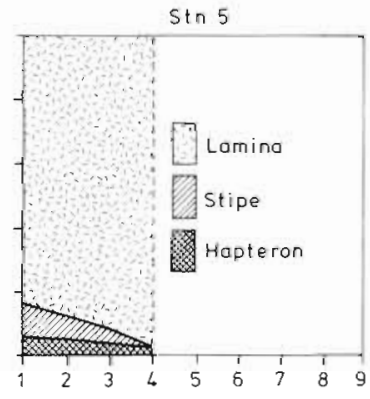

Fig. 5. Allocation of estimated total annual biomass production to lamina, stipe and hapteron tissue in each age group. Stations are arranged according to estimated value of wave exposure. Stippled line age groups lacking in the sample; $\mathrm{n}=4$ to 112 


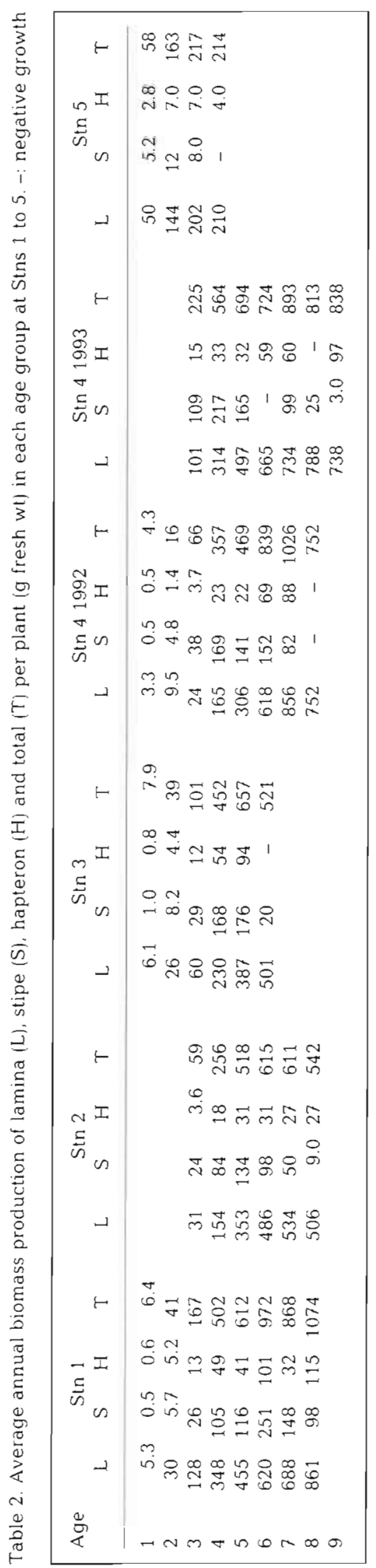

At Stns 2 to 4 stipe production tended to reach a maximum (between 35 and $60 \%$ ) in the intermediate age groups (Fig. 5). This tendency was most pronounced at Stn 4, where peak stipe production amounted to between 50 and $60 \%$ of total production in 3 yr old plants. The high allocation of growth to the stipe in the intermediate age groups is not an artifact caused by reduced lamina biomasses, as lamina production (fresh wt) is shown to increase with increasing age up to about 7 yr old (Table 2).

At Stn 4 the estimates of growth allocation derived from the 1992 and 1993 samples differed somewhat (Fig. 5). However, the general trend was similar in both samples. Lamina growth accounted for more than $70 \%$ of total growth in plants more than $5 \mathrm{yr}$ old in both years. In both samples, maximum allocation of total growth to the stipes was found in 3 yr old plarts.

The hapteron and stipe weight of a plant represent accumulated growth during its life span. In 1 yr old plants, hapteron and stipe growth were about equal in terms of net biomass increase at all stations (Fig. 7). Except at Stn 5, where the ratio between hapteron and stipe weight remained between 0.65 and 1, there was a general decrease in the ratio with increasing age at all stations, resulting in a ratio between hapteron and stipe weight of between 0.15 and 0.55 in plants older than 3 yr (Fig. 7). The decrease was most pronounced at $\operatorname{Stn} 4$, where the ratio between hapteron and stipe weight decreased from about 1.5 in 1 yr old plants to about 0.4 in 2 yr old plants. At Stns 2 \& 4 a slightly lower ratio was found in intermediate age groups than in the older plants.

Growth of lamina and stipe during one season. Average stipe growth from February to June was found to vary between 10 and $110 \mathrm{~g}$ fresh wt per plant

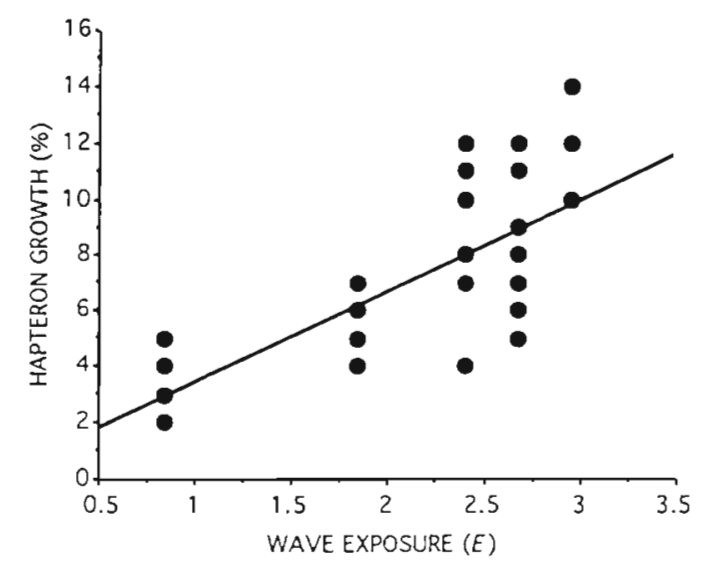

Fig. 6. The proportion of hapteron growth (\%) as a function of log-transformed estimated degree of wave exposure $(E)$ at the stations. Age groups which appeared with negative hapteron growth (due to methodical problems) are not included 


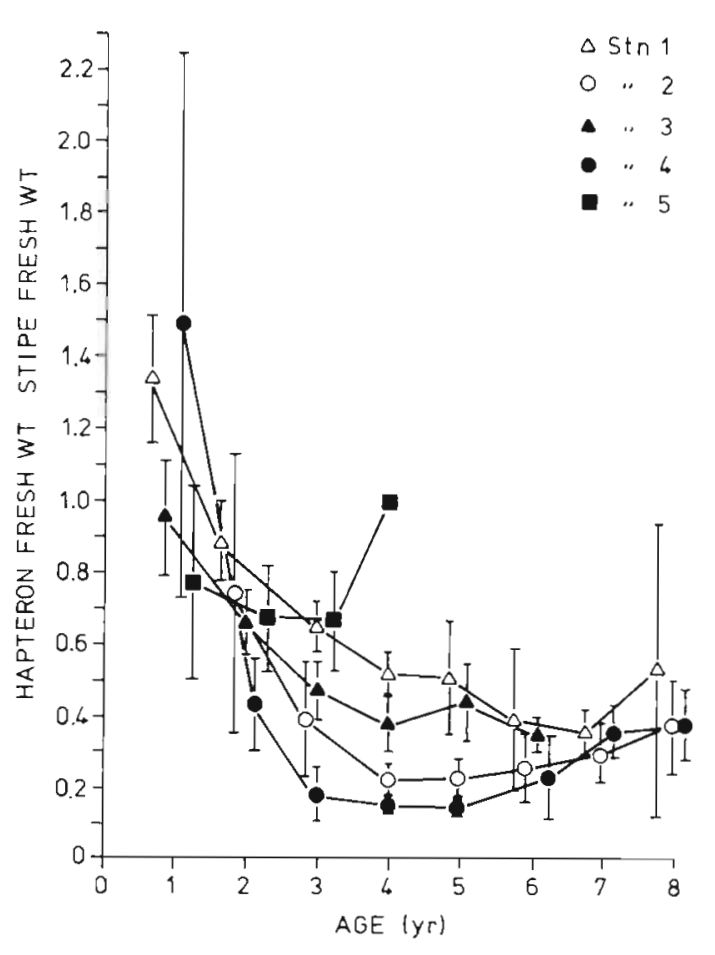

Fig. 7. Average ratios between hapteron and stipe fresh wt with $95 \%$ confidence limits. Confidence limits which include zero are not shown; $n=3$ to 99

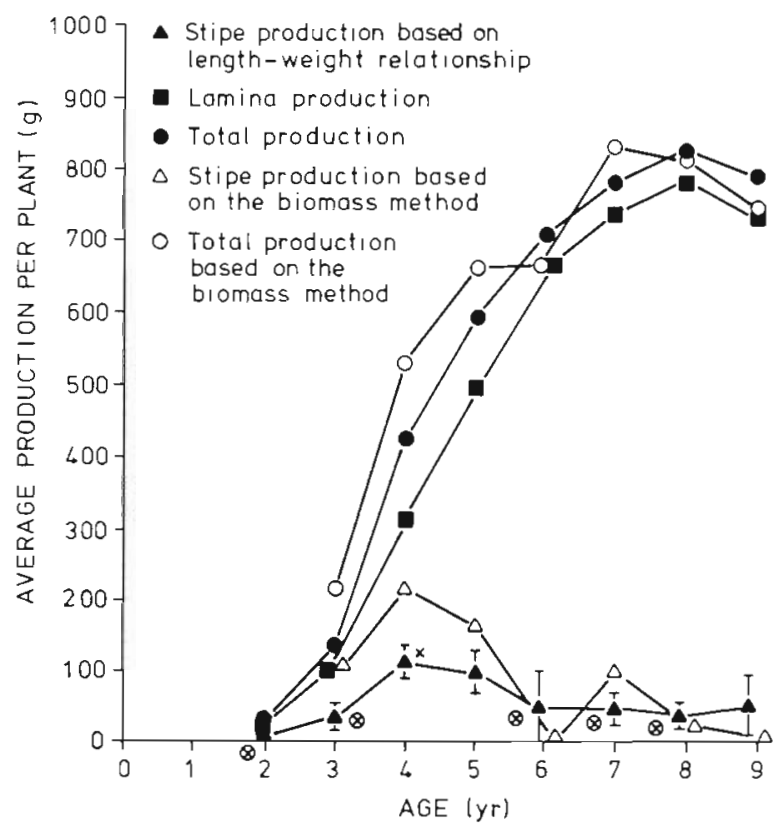

Fig. 8. Average annual biomass production (stipe, lamina and total) per plant at Stn 4 in 1993. Average stipe production of individual tagged plants is shown with $95 \%$ confidence limits, the age group marked $(x)$ is significantly higher than the stipe growth in the age groups marked $(\otimes)$ (Tukey test, $\mathrm{p}<0.05) ; \mathrm{n}=4$ to 22

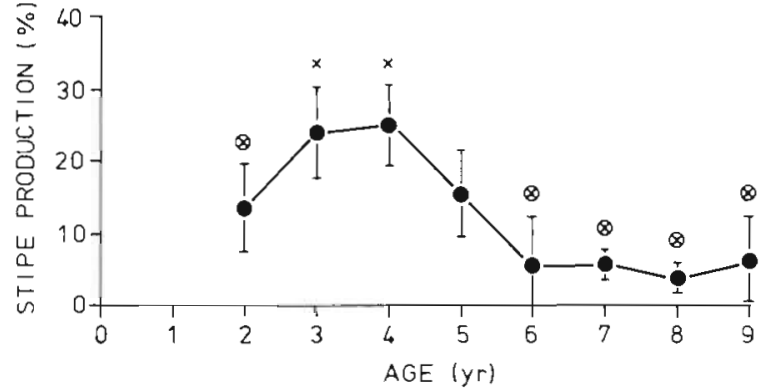

Fig. 9. Percentage of stipe production from February to June 1993 at Stn 4 . Average values with $95 \%$ confidence intervals are given. Allocation of seasonal growth to the stipe is significantly higher in age groups marked $(x)$ than in those marked $(\otimes)$ (Tukey test, $\mathrm{p}<0.05$ ); $\mathrm{n}=4$ to 22

in the different age groups when calculated from length-weight relationships (Fig. 8). The highest stipe growth was found in 4 and 5 yr old plants. Stipe growth in $4 \mathrm{yr}$ old plants was significantly higher than in 6 to 8 yr old plants (Fig. 8). Also when calculating stipe production by using the biomass method of Bellamy et al. (1973), maximum values (150 to $200 \mathrm{~g}$ fresh wt per plant) in 4 and 5 yr old plants and lower stipe production in older plants were found (Fig. 8). In plants more than 5 yr old, lamina growth accounted for nearly all net production according to both methods. Lamina growth increased with age until the plants were about $7 \mathrm{yr}$ old, and in 7 to $9 \mathrm{yr}$ old plants the maximum net growth per plant was about $800 \mathrm{~g}$ fresh wt according to both methods (Fig. 8).

The proportion of total growth which took place in the stipe varied with the age of the plants (Fig. 9). The proportion was highest in 3 and 4 yr old plants, in which average proportion of stipe growth amounted to about $25 \%$ of total growth, which was significantly higher than in 2 and 6 to 9 yr old plants (Fig. 9).

\section{DISCUSSION}

\section{Stipe growth calculated by 2 methods}

According to both methods the stipe growth (in fresh wt) showed a peak in 4 to $5 \mathrm{yr}$ old plants and was reduced in older plants at Stn 4. Maximum allocation of growth to the stipe (in \%) occurred in 3 to 4 yr old plants according to both methods. Because there were no 1 yr old plants among the tagged plants, it is not possible to compare the 2 methods with regard to stipe growth of the youngest plants.

Calculating stipe growth by using the length-weight relationships of individual stipes resulted in a lower stipe growth than the biomass method in 2 to 5 yr old plants. This lower growth may be because growth of 
individual stipes was calculated only during part of the year, and some stipe growth also seems to occur during summer (Gunnarsson 1991). Only the biomass method includes stipe growth during the whole year. We therefore suggest that the biomass method gives the most adequate estimate of stipe growth.

\section{Morphological changes related to environmental conditions}

Plants at a depth of $5 \mathrm{~m}$ had probably grown under fairly similar light and temperature conditions, since both sets of stations were situated in open coastal areas and exposed to strong tidal currents. However, wave exposure at the localities varied considerably. Wave exposure is probably the factor which has most influence on the morphology of Laminaria hyperborea (Kain 1967, Kain 1971a, Svendsen \& Kain 1971). Surge results in a back-and-forth streaming of the water near the bottom (Neushul 1972). Strong currents may influence kelp morphology much in the same way as wave exposure does, but can also result in development of special morphological features (Norton 1969). L. hyperborea develops a longer and more narrow lamina in a strong current than at wave-exposed sites (Kain 1971b). The method of estimating wave exposure presented here does not take into account the effect of tidal currents or the possible influence of subtidal topography on wave movements. However, since there were no pronounced differences with regard to the current at the examined localities, we concluded that the differences in wave exposure was a more important factor for the plant morphology than minor differences in the tidal current. For the purpose of this study the method provided an adequate way of ranking the localities according to wave exposure.

In the Laminaria longicruris-saccharina group, a clinal differentiation of stipe morphology with increasing wave exposure was reported (Chapman 1973, Kain 1976b). When comparing a sheltered and a waveexposed population, Chapman (1974) found a high genetic component in the interpopulation differentiation. Likewise, a genetic differentiation may exist between $L$. hyperborea from wave-exposed and sheltered sites. However, the wave-exposed forms of $L$. hyperborea have not been reported from sheltered areas, and the result of transplant experiments indicated that the morphological differentiation was a phenotypic response (Svendsen \& Kain 1971).

At the most sheltered station of the present study the ratio between lamina and stipe weight was similar to what Kain (1971a) found in Laminaria hyperborea f. cucullata. At the more wave-exposed locali- ties a greater proportion of total growth took place in the stipe, resulting in decreasing lamina to stipe ratios with age. However, when comparing the more wave-exposed localities no gradual decrease in lamina to stipe ratio with increasing wave exposure was found. Thus, lamina to stipe ratios intermediate between 10 (L. hyperborea f. cucullata) and 1 to 2 ( $L$. hyperborea f. hyperborea) were not observed among the oldest plants. Kain (1971a) compared the kelp vegetation at several localities and found $L$. hyperborea f cucullata at a locality which seemed to be only slightly more sheltered than a site where the typical $L$. hyperborea grew. The change in morphology may be triggered by a relatively small difference in exposure, or other environmental factors in addition to wave exposure may influence lamina and stipe accretion.

Developing a large and thin blade is of adaptive significance for algae, by e.g. increasing the amount of photosynthetic tissue in relation to nonphotosynthetic tissue. However, in Laminaria hyperborea high production is associated with the wave-exposed morphology (Kain 1977), in contrast to L. longicruris (Gerard \& Mann 1979).

The results show that an increased allocation of growth to hapteron growth takes place when the plants are subjected to high wave exposure. This may be of adaptive significance in Laminaria hyperborea, because it will probably increase the chances of the plant surviving at wave-exposed sites. However, hapteron growth was not measured in individual plants, but calculated as the average weight difference between the haptera of one age group and the next. If plants with low hapteron growth are more susceptible to detachment at wave-exposed localities, hapteron growth would be overestimated

Plants with exceptionally long stipes in relation to weight have been reported from some populations, and it has been suggested to be an 'etiolation' effect caused by reduced light levels (Bellamy \& Whittick 1968). However, Kain (1971a) found no indications of 'etiolation' in stipes growing in deep water and low light levels. In the present study a divergent stipe allometry was found at the station where the density of canopy plants was highest, and where light penetration will be reduced most (Stn 4 ). The plants had comparatively long stipes in relation to weight, which was probably due to thinner stipes at a given length at this station than at the others. Also, Holbrook et al. (1991) found that Postelsia palmaeformis in dense stands had thinner stipes in relation to length than was the case in isolated plants. This supports the suggestion that some aspect of the light environment may influence stipe morphology in kelps. 


\section{Morphological changes related to age}

Since Laminaria hyperborea is perennial, the morphology of the plants can be modified throughout their life span. Higher allocation of growth to the stipes in plants that are more than 1 yr old leads to the formation of the 'typical' L. hyperborea morphology.

In 1 yr old plants, a high part of the total growth occurred as lamina growth at all sites. In a kelp forest, young Laminaria hyperborea plants experience a different environment from older plants, especially with respect to light. The growth of understorey plants is probably light-limited in dense kelp forests (Kain $1976 \mathrm{c})$. The high allocation of growth to the lamina in the youngest plants means that much of the total growth was invested in photosynthetic tissue. This may be interpreted as an adaptive strategy for growth in a low-light environment. Hapteron growth in relation to stipe growth was also found to be high in the youngest plants. The results indicate that in juvenile plants, growth is primarily allocated to the development of photosynthetic tissue, and to tissue which anchors the plant to the substrate. This pattern of growth allocation in the youngest $L$. hyperborea may be an ontogenetic feature. One year old plants were probably subjected to more water movement at the most waveexposed locality than at the most sheltered locality, but showed the same pattern of growth allocation at both localities.

The highest allocation of growth to the stipe was found in the intermediate age groups ( 3 and 4 yr old plants) at the locality with the highest density of large plants and with intermediate wave exposure (Stn 4). The number of plants below the canopy layer was low, which suggests light-limited growth (Kain 1963, 1977). In contrast, at the station with the lowest density of large plants and intermediate wave exposure (Stn 1) plants of the intermediate age groups showed a comparatively low allocation of annual growth to the stipes. This indicates that light-limited growth results in allocation of growth to the stipe in plants older than $1 \mathrm{yr}$, and that the light environment in addition to the degree of wave exposure influence the stipe and lamina accretion in Laminaria hyperborea. Increased allocation of growth to the stipe is not accompanied by increased hapteron growth, as 3 and 4 yr old plants at Stn 4 had a low hapteron to stipe ratio.

High allocation of annual growth to the stipe can be interpreted as a phenotypical response to environmental factors. A long and flexible stipe may be advantageous for Laminaria hyperborea at wave-exposed sites, by for example allowing the bulk of lamina to follow the waves to some degree. This will reduce the acceleration reaction force on the plants (Koehl 1986). Because the canopy-forming layer reduces the light available for the smaller plants, allocation of growth to the stipe in the subcanopy plants can be of adaptive significance in a species which forms dense monospecific stands. Maximum allocation of annual growth to the stipe was found in 3 and 4 yr old plants at Stn 4 , and by comparing Figs. $2 \& 4$ we see that the stipe growth in these 2 age groups brought the plants into the size classes of the canopy plants. In L. hyperborea the compensation point for photosynthesis shifts from about 1 to $2 \mu \mathrm{gcal} \mathrm{cm}^{-2} \mathrm{~s}^{-1}$ in microscopic sporophytes (Kain 1969) to about $50 \mu \mathrm{gcal} \mathrm{cm} \mathrm{cm}^{-2} \mathrm{~s}^{-1}$ in new lamina of large plants (Lüning 1971). Small plants may grow in very low light levels, but require more light as they grow larger. Allocation of more growth to the stipe in a dense stand may increase the chances of small plants to reach improved light levels in the canopy layer.

Whereas the highest proportion of seasonal growth was distributed to the stipes in 3 and 4 yr old plants in a dense kelp forest, maximum biomass increase of the stipes was found in 4 and 5 yr old plants. Thus, after the plants have become part of the canopy layer, a period of high stipe growth precedes reduced stipe growth in older plants. The age at which maximum stipe growth takes place seems to vary in Laminaria hyperborea populations. In Iceland, Gunnarsson (1991) found that the period of rapid stipe growth started in 3 to 4 yr old plants and continued until the plants were about 10 to $11 \mathrm{yr}$ old. Kain (1977) found that the age at which the plants reduced the stipe growth varied between 3 and 7 yr.

Reduced stipe growth of old plants can be a growth response to the improved light environment in the upper canopy layer. Gendron (1989) observed reduced stipe growth in Laminaria longicruris in shallow water. Alternatively, the increased growth of epiphytes on the stipes of old plants may reduce their photosynthetic capacity and thereby stipe growth. However, translocation of photosynthetic products from lamina to stipe has been observed in L. hyperborea (Schmitz et al. 1972), which indicates that stipe growth is not exclusively dependent on the stipe's own production. Lüning (1970) suggests that the lamina supports stipe growth in older plants whose stipes are covered with epiphytes.

The stipes of the oldest age groups tended to be of similar size at the various localities. This is probably a result of both low stipe growth in the oldest plants and selective dislodgement of the largest plants by wave action.

Acknowledgements. The investigation was supported by the Research Programme on North Norwegian Coastal Ecology (MARE NOR). We are grateful for helpful comments on the manuscript from Jan Rueness and Tore Høisæter We would like to thank Siri Odegaard, Eirik Brynjelsen, Trond Wahl, 
Hartvig Christie and Arnfinn Skadsheim for diving assistance, Helge Ullebust for help with the statistical analyses and Elin Holm for drawing the figures. The Norwegian Meteorological Institute kindly provided data on wind force and frequency.

\section{LITERATURE CITED}

Baardseth E (1970) A square-scanning, two-stage sampling method of estimating seaweed quantities. Norw Inst Seaweed Res 33:1-41

Bellamy DJ, Whittick A (1968) Problems in the assessment of the effects of pollution on inshore marine ecosystems dominated by attached macrophytes. In: Carthy JD, Arthur Don R (eds) The biological effects of oil pollution on littoral communities. Supplement to Vol 2 of Field Studies, Field Studies Council, London, p 49-54

Bellamy DJ, Whittick A, John DM, Jones DJ (1973) A method for the determination of seaweed production based on biomass estimates. Monogr Oceanogr Methodol UNESCO 3:27-33

Chapman ARO (1973) Phenetic variability of stipe morphology in relation to season, exposure and depth in the non-digitate complex of Laminaria Lamour. (Phaeophyta, Laminariales) in Nova Scotia. Phycologia 12:53-57

Chapman ARO (1974) The genetic basis of morphological differentiation in some Laminaria populations. Mar Biol 24:85-91

Gendron L (1989) Seasonal growth of the kelp Laminaria longlcruris in Baie des Chaleurs, Québec, in relation to nutrient and light availability. Bot Mar 32:345-354

Gerard VA, Mann KH (1979) Growth and production of Laminaria longicruris (Phaeophyta) populations exposed to different intensities of water movement. J Phycol 15: $33-41$

Gunnarsson K (1991) Populations de Lammaria hyperborea et Laminaria digitata (Phéophycées) dans la baie de Breidifjördur, Islande. Rit Fiskideildar 12:1-148

Holbrook NM, Denny MW, Koehl MAR (1991) Intertidal 'trees' consequences of aggregation on the mechanical and photosynthetic properties of sea-palms Postelsia palmaeformis Ruprecht. J exp mar Biol Ecol 146:39-67

Kain JM (1963) Aspects of the biology of Laminaria hyperborea. II. Age, weight and length. J mar biol Ass UK 43: $129-151$

Kain JM (1967) Populations of Laminaria hyperborea at various latitudes. Helgoländer wiss Meeresunters 15:489-499

Kain JM (1969) The biology of Laminaria hyperborea. V. Comparison with early stages of competitors. $J$ mar biol Ass UK 49:455-473

Kain JM (1971a) The biology of Laminana byperborea. VI. Some Norwegian populations. J mar biol Ass UK 51: $387-408$

Kain JM (1971b) Synopsis of biological data on Laminaria hyperborea. FAO Fish Synopses 87

Kain JM (1976a) The biology of Laminaria hyperborea. IX. Growth pattern of fronds. J mar biol Ass UK 56:603-628

This article was submitted to the editor
Kain JM (1976b) New and interesting marine algae from the Shetland Isles. II. Hollow and solid stuped Lamnaria (Simplices). Br phycol J 11:1-11

Kain JM (1976c) The biology of Laminaria hyperborea. VIII. Growth on cleared areas. J mar biol Ass UK 56:267-290

Kain JM (1977) The biology of Laminaria hyperborea. X. The effect of depth on some populations. J mar biol Ass UK 57 : $587-607$

Koehl MAR (1986) Seaweeds in moving water: form and mechanical function. In: Givnish TJ (ed) On the economy of plant form and function. Cambridge University Press, Cambridge, p 603-634

Lüning K (1970) Cultivation of Laminaria hyperborea in situ and in continuous darkness under laboratory conditions. Helgoländer wiss Meeresunters 20:79-88

Lüning K (1971) Seasonal growth of Laminaria hyperborea under recorded underwater light conditions near Helgoland. In: Crisp DJ (ed) Proceedings of the IVth European Marine Biology Symposium. Cambridge University Press. Cambridge, p 347-361

Neushul M (1972) Functional interpretation of benthic marine algal morphology. In: Abbott IA, Kurogi $M$ (eds) Contributions to the systematics of benthic algae in the North Pacific. Japanese Society of Phycology, Tokyo, p 47-73

Norton TA (1969) Growth form and environment in Saccorhiza polyschides. J mar biol Ass UK 49:1025-1045

Norton TA, Hiscock K, Kitching JA (1977) The ecology of Lough Ine. XX. The Laminaria forest at Carrigathorna. J Ecol 65:919-941

Norton TA, Mathieson AC, Neushul M (1981) Chap 12, Morphology and environment. In: Lobban CS, Wynne MJ (eds) The biology of seaweeds. Botanical Monographs Vol 17, Blackwell Scientific Publications, p 421-451

Oug E, Lein TE, Holte B, Ormerod K, Næs K (1985). Basisundersøkelse i Tromsøsund og Nordbotn 1983. Bløtbunnsundersøkelser, fjæreundersøkelser og bakteriologi. Niva-rapport, overvakingsrapport nr $173 \mathrm{~b} / 84$, Oslo

Schmitz $K$, Lüning $K_{r}$ Willenbrink $J(1972)$. $\mathrm{CO}_{2}$-Fixierung und Stofftransport in benthischen marinen Algen. II. Zum Ferntransport ${ }^{14} \mathrm{C}$-markierter Assimilate bei Laminaria hyperborea und Laminaria saccharina. Z Pfl Physiol 67: $418-429$

Sivertsen K (1991) Hosting avstortare og gjenvekst avtare etter taretrảing ved Smøla, More og Romsdal. Fisken og Havet nr 1/91:1-44

Sjotun K, Fredriksen $S$, Lein TE, Rueness R, Sivertsen $K$ (1993) Population studies of Laminaria hyperborea from its northern range of distribution in Norway. Hydrobiologia 260/261:215-221

Sundene $O$ (1964) The ecology of Laminaria digitata in Norway in view of transplant experiments. Nytt Mag Bot 11:83-107

Svendsen P, Kain JM (1971) The taxonomic status, distribution and morphology of Laminaria cucullata sensu Jorde and Klavestad. Sarsia 46:1-22

Zar JH (1984) Biostatistical analysıs, 2nd edn. Prentice-Hall, Inc., Englewood Cliffs, NJ

Manuscript first received: October 21, 1994

Revised version accepted: April 21, 1995 